\title{
GLOBAL ENVIRONMENT AS A FACTOR OF CHANGES IN ORGANIZATION AND MODERN MANAGEMENT CONCEPTS
}

\author{
Jerzy WĄCHOL \\ AGH University of Science and Technology, Kraków; jwachol@zarz.agh.edu.pl, ORCID: 0000-0003-0296-0585
}

Purpose: The aim of the study is to present a changing global environment for businesses, to use modern elements of management, IT and telecommunications as necessary elements in the face of the pandemic and global crisis, to sustain the functioning of businesses, organisations, economies and states.

Design/methodology/approach: On the basis of the collected statistical data, own research and surveys, observations and literature, conclusions have been drawn concerning trends of changes in the organisation and the application of modern management concepts and forms of management. The study presents the functioning of enterprises taking into account their further environment, especially economic and social, against the background of the current problems of the EU and the world economy. The study also presents the problems of modern global economy, pandemic and sustainable development.

Findings: Study presents selected elements of governance and trends of change in the organisation. What matters most for companies is marketing, finance, profit, strategies, personnel, innovation, modern methods and forms of organisation, etc. However, elements of IT and modern management methods already have an important and growing position, especially in the face of the pandemic, remote work and the global crisis. Technological and macro-economic changes, new methods of management, shrinking natural resources in the world at the turn of the 20th and 21st century, looking for substitutes, all these set out the directions for the development of companies. In addition, socio-political and epidemiological changes, computerisation and automation, cause changes in the functioning of enterprises, both large and small.

Keywords: Global environment, process organizations, modern management methods, global economy, sustainable development, trends in organization, sustainable development.

\section{Introduction}

With the ongoing SARS-CoV-2 pandemic, the rapid changes in the global environment and the political, social and economic problems of the European Union, businesses and citizens need to adapt quickly in order to earn money and survive. These are not only economic, legal, 
political, technological and IT changes, new methods of management, which are difficult not to follow, but also changes in the socio-cultural environment, the mixing of cultures, and changes in the environment. These changes are being created at global level, at the level of the European Union as a whole and of individual diverse nation states. The challenges for businesses are certainly very great. There are possible next different waves of epidemics, terrorism or states of emergency, which can disturb economic stability, usually so important for companies and their strategic plans (Kapferer, 2012). Especially during the epidemic, it turned out that IT and telecommunications can be used very often, in many cases for remote work in companies, or in organisations such as state government, local government or education (www.computerworld.pl/...). It is possible to hold virtual meetings, teleconferences, do the shopping without leaving home. You can work remotely from home, sending the administrative support items to the headquarters. Similarly, you can perform other commissioned work at home, but here you need couriers. IT and telecommunications are useful on a massive scale for remote medical advice, e-prescriptions, with the possibility of some remote medical examinations. However, the network traffic load was record-breaking (www.komputerswiat.pl/...). It has happened many times that networks as well as local servers and software have failed, due to too many active participants and sophisticated IT processes, also not without significance have hackers been.

The aim of the study is to present a changing global environment for businesses, to use modern elements of management, IT and telecommunications as necessary elements in the face of the pandemic and global crisis, to sustain the functioning of businesses, organisations, economies and states. On the basis of available sources, own research, conclusions were presented concerning the problems of the modern economy, trends in change, during the pandemic and crisis. Emphasis is also placed on technological and environmental changes.

\section{IT, telecommunications and the virtualisation of economic and social processes, and the impact of the epidemic on the economy}

The use of IT and telecommunications is widespread, so if it is cheaper and quicker to do something without leaving home, then it may be worth doing so using IT. The habits of societies acquired during the pandemic of spring 2020 are also an issue, and I believe this will continue to be the case for years to come even without epidemics or similar crisis threats. Provided that, technologically, Internet networks can withstand the growing burden, they are maintained, developed and modernised. However, there are problems and costs. You have to have good computer equipment, servers, Internet and telephone links, radio links, etc. everywhere. And there must also be conditions in the home for remote working, which requires investment outlays. In this case, there are less costs for commuting, but the costs for electricity, computer 
equipment, internet and telecommunication links are rising. Remote working, shopping, education, meetings, medical advice, cashless payments, etc. using IT and telecommunications, are likely to take on even greater significance, even if there are no more pandemics and similar threats (www.pulshr.pl/...).

This is all the more important in view of the next epidemic season in the autumn of 2020 , and the possible next waves of epidemics in the next few years. The SARS-CoV-2 virus is constantly mutating, and more vaccines and medicines will be needed, just as for influenza. The mortality rate of COVID-19 is relatively low for the time being, but the disease is dangerous, severe and very contagious. It affects not only older people, but also younger and younger people, and there are already millions of people infected in the world. Far Eastern societies such as China, North Korea and Japan, which have been accustomed to constant epidemics for many years, are more prepared and disciplined to prevent another wave of the pandemics. In America and Europe, however, this is still a major problem and the pandemic is developing rapidly, even at an exponential rate. It is certainly also a great problem for the global economy.

Scientific and technological achievements gained in one country can be used in industry in a completely different distant country, in the world of a global economy. Skilful use of available knowledge and technology becomes a necessity for the survival of organisations. Once discovered, knowledge, technology and experience usually spread around the world over time thanks to, among other things, IT, and skilful computer-based storage of these achievements also allows for their analysis and transfer (Kasprzak, 2003).

To achieve success, the following are important: assumptions, strategy, good data for the system, storage, selection, processing and analysis of information, for creating currently needed knowledge and technology, on the one hand, and loading currently needed knowledge into the operational area from available archives, knowledge warehouses, on the other hand. So that the IT system is not overloaded with unnecessary data and knowledge, so that it can work quickly and effectively at a given technological level, providing good analysis results, and suggest solutions thanks to artificial intelligence. Effective process management (Kalinowski, 2015) with the use of information technology can be useful here.

Global data indicate that achieving economic success usually goes hand in hand with knowledge, modern technologies and the skilful use of IT and multimedia means; health care and the environment are also important. Moreover, in the future, societies will probably become more accustomed to using these measures wherever possible and wherever this makes sense.

In the 21 st century, it is IT that dominates everywhere, even among other technologies. They apply to the modern economy (mfiles.pl/...), especially in the so-called fourth industrial revolution (Schwab, 2018).

The new century (21st century) is often called the IT and communication era. However, if we analyse more deeply what this IT is supposed to do, we will come to the conclusion that this is consequently a knowledge society, because by analysing information, knowledge is 
created. In such a society, knowledge workers will play a major role, because it is the broad knowledge they possess that will be the main commodity.

The modern use of IT and multimedia in companies and organisations is, of course, very large, important and extensive. It is difficult to imagine how businesses and households might function today in economically developed societies without Internet technologies and multimedia. They have become one of the most important elements of life and functioning of organisations.

Efficient elements of communication, control, automation, information exchange and processing are very important in the computerisation process. As well as elements of training and stable power supply and the high costs associated with this, not only calculated in money for computer hardware, software and electricity, but also ecological costs. The question is, therefore, whether the excessive use of IT is always necessary today, on a large scale? After all, in the past, businesses were also able to operate efficiently without IT. However, the environment in which businesses operate has changed, and this is forcing changes in the direction of digitisation, especially in times of a global pandemic.

\section{The global economic crisis and the pandemic vs. the functioning of IT and modern management methods in a new environment}

The economic crisis, with the current epidemic, is a special time to test and use modern management concepts, crisis management methods and IT systems and telecommunications multimedia means, which is necessary to stop the spread of viruses, bacteria, on the one hand, and to slow down the economic and social crisis, on the other. Thanks to IT systems, it is possible for the economy and the state to function, and the IT industry is growing in strength (cyfrowa.rp.pl/...). Employees in this sector are in demand, unlike many other sectors of the economy, which has resulted in losses and redundancies, particularly in tourism, the hotel and catering industry, and so on.

In highly developed and rich countries, where IT is widely used, and where IT societies make use of computer networks and systems and modern telecommunications connections almost in $100 \%$, it is easier to use these technologies to combat the pandemic, which may limit this phenomenon. However, when it comes to stopping the negative economic phenomena which are leading to the economic crisis, it is much more difficult. There may no longer be the pandemic, but the economic crisis will continue, not only because of the SARS-CoV-2 coronavirus or its mutation, but also because of the accumulation of economic and social problems from previous years, even earlier than the last global economic crisis reported for 2008. 
Table 1 presents selected countries of the world from those more significant in economic terms, and those close to Poland and their GDP growth forecasts, together with unemployment figures for 2020. The forecasts are according to the IMF from May 2020.

Table 1.

The forecasts of GDP growth and unemployment in selected world countries

\begin{tabular}{|c|c|c|c|c|c|}
\hline \multirow[t]{2}{*}{$\begin{array}{l}\text { Country/ } \\
\text { Region }\end{array}$} & \multicolumn{2}{|c|}{$\begin{array}{c}\text { The forecasts of GDP } \\
\text { dynamics for } 2020\end{array}$} & \multirow{2}{*}{$\begin{array}{c}\text { The most likely GDP } \\
\text { dynamics in } \mathbf{2 0 2 0} \\
\%\end{array}$} & \multicolumn{2}{|c|}{ Unemployment/period } \\
\hline & from $\%$ & up to $\%$ & & $\%$ & period \\
\hline Grecja & $\downarrow-10$ & -5 & $-10,0$ & 16,2 & 02.2020 \\
\hline Włochy & -10 & -5 & $-9,1$ & 8,0 & 04.2020 \\
\hline Litwa & -10 & -5 & $-8,1$ & 11,2 & 05.2020 \\
\hline Hiszpania & -10 & -5 & $-8,0$ & 13,8 & 03.2020 \\
\hline Ukraina & -10 & -5 & $-7,7$ & 8,7 & 03.2020 \\
\hline Francja & -10 & -5 & $-7,2$ & 8,1 & 03.2020 \\
\hline Holandia & -10 & -5 & $-7,2$ & 2,9 & 04.2020 \\
\hline Niemcy & -10 & -5 & $-7,0$ & 3,5 & 04.2020 \\
\hline Austria & -10 & -5 & $-7,0$ & 12,8 & 05.2020 \\
\hline Szwecja & -10 & -5 & $-6,8$ & 7,1 & 04.2020 \\
\hline Australia & -10 & -5 & $-6,7$ & 6,2 & 04.2020 \\
\hline Czechy & -10 & -5 & $-6,5$ & 3,7 & 05.2020 \\
\hline Wielka Brytania & -10 & -5 & $-6,5$ & 4,0 & 03.2020 \\
\hline Norwegia & -10 & -5 & $-6,3$ & 3,5 & 03.2020 \\
\hline Słowacja & -10 & -5 & $-6,2$ & 5,2 & 04.2020 \\
\hline Kanada & -10 & -5 & $-6,2$ & 13,0 & 05.2020 \\
\hline USA & -10 & -5 & $-5,9$ & 14,7 & 05.2020 \\
\hline Rosja & -10 & -5 & $-5,5$ & 4,7 & 04.2020 \\
\hline Brazylia & -10 & -5 & $-5,3$ & 12,2 & 04.2020 \\
\hline Japonia & -10 & -5 & $-5,2$ & 2,5 & 04.2020 \\
\hline Turcja & -5 & 0 & $-5,0$ & 13,8 & 02.2020 \\
\hline Polska & -5 & 0 & $-4,6$ & 5,4 & 04.2020 \\
\hline Arabia Saudyjska & 0 & -5 & $-2,3$ & 5,7 & 01.2020 \\
\hline Korea Południowa & 0 & -5 & $-1,2$ & 3,8 & 05.2020 \\
\hline Chiny & 0 & +5 & $+1,2$ & 5,9 & 04.2020 \\
\hline Indie & 0 & +5 & $+1,9$ & 23,5 & 05.2020 \\
\hline
\end{tabular}

Source: Own study based on https://www.forbes.pl/gospodarka/koronawirus-prognozy-gospodarcze$\mathrm{mfw} / \mathrm{d} 742 \mathrm{kyd} \quad 30.05 .2020$, and https://www.obserwatorfinansowy.pl/bez-kategorii/rotator/niewszystkie-gospodarki-wpadna-w-recesje/, 30.05.2020.

The current data and the forecasts are even being tragic for the global economy, which is predicted to contract by $3 \%$ or more of GDP. Many countries will fall into recession and high unemployment, as predicted by, among others, the IMF (International Monetary Fund) (www.forbes.pl/...). According to these predictions, the world is threatened by a global recession, on a large scale, similar to the crisis of 1929-1933, which further ended in the Second World War. According to these forecasts, most of the economically significant countries in the world which have modern technologies, including IT, may have negative GDP dynamics and an increase in unemployment. This does not, however, apply to China, which, after a significant economic slowdown from around 7\%, could achieve still positive GDP growth of $+1.2 \%$ in 2020 , and perhaps India of $+1.9 \%$. The next wave of the pandemic in the autumn of 2020 does not, as yet, affect significantly countries in the Far East, such as China, Japan, South Korea and 
so on. These countries, which have been accustomed to various epidemics for many years, are able to overcome them more easily.

However, the whole of the so-called West, including the countries of Central and Eastern Europe and Russia, have negative GDP growth forecasts for 2020. The question is only how negative they are. According to forecasts, Greece is expected to have the highest negative GDP growth rates, viz. $-10 \%$, and then Italy $-9.1 \%$, Lithuania $-8.1 \%$, Spain -8.5 , Ukraine $-7.7 \%$, France $-7.2 \%$, the Netherlands $-7.2 \%$, Germany $-7.0 \%$ and so on. The recession and the negative forecast of GDP growth will also affect the USA (-5.9\%) with rapidly rising unemployment. Due to the dramatic fall in oil prices in March 2020, caused by falling demand, oil-producing countries such as Russia, Saudi Arabia, Norway, etc. are also experiencing major economic problems and limiting production.

The use of IT and other selected management elements is presented in Table 2.

\section{Table 2.}

The usefulness and application of selected elements in the management

\begin{tabular}{|c|c|c|c|c|c|c|c|c|c|}
\hline & \multirow[t]{2}{*}{$\begin{array}{c}\text { Number of } \\
\text { responses/element } \\
\text { management }\end{array}$} & \multirow[t]{2}{*}{$\begin{array}{l}\text { Weighted average } \\
\text { rating the } \\
\text { suitability of } \\
\text { selected elements in } \\
\text { the management } \\
1 \quad \text { scale } 1-5\end{array}$} & \multicolumn{5}{|c|}{$\begin{array}{l}\text { Number of ratings, scale } \\
\text { of } 1-5 \text { for the suitability of } \\
\text { the selected items in the } \\
\text { management, } \\
(1 \mathrm{~min}, 5 \text { max })\end{array}$} & \multicolumn{2}{|c|}{$\begin{array}{l}\text { The using of these } \\
\text { elements in the } \\
\text { organization, where } \\
\text { respondents work, } \\
\text { by their reviews }\end{array}$} \\
\hline & & & 1 & 2 & 3 & 4 & 5 & Yes & No \\
\hline 1 & Marketing & 4,425 & 0 & 0 & 4 & 15 & 21 & 33 & 7 \\
\hline 2 & Financial management & 4,300 & 0 & 3 & 2 & 15 & 20 & 31 & 9 \\
\hline 3 & Business plan & 4,150 & 1 & 3 & 4 & 13 & 19 & 35 & 5 \\
\hline 4 & HR & 4,050 & 1 & 4 & 7 & 8 & 20 & 31 & 9 \\
\hline 5 & IT & 3,975 & 1 & 1 & 11 & 12 & 15 & 32 & 8 \\
\hline 6 & Outsourcing & 3,675 & 2 & 0 & 12 & 21 & 5 & 30 & 10 \\
\hline 7 & Lean Management & 3,675 & 1 & 1 & 14 & 18 & 6 & 21 & 19 \\
\hline 8 & Ecology & 3,525 & 2 & 4 & 11 & 17 & 6 & 20 & 20 \\
\hline 9 & Virtual organization & 3,500 & 2 & 4 & 13 & 14 & 7 & 22 & 18 \\
\hline
\end{tabular}

Source: Own surveys September 2019 in SME sector, Malopolska and Krakow.

The entrepreneurs of the future are facing new challenges in today's global IT economy and within a changing EU. They are related to the changing environment and the constantly growing processes of globalisation (Borowiecki, 2010), the company's environment is presented in Fig. 1. In the case of advanced, expanding globalisation processes, the area of the global environment is becoming more and more important for further companies in a given country, including Poland. This obviously raises specific problems in the socio-cultural, political and legal, macroeconomic and technological fields. This may concern the natural environment in a given country. This may represent new opportunities and threats for businesses in that country. The economic problems in a changing and undefined environment, which Polish companies face, are very complex. This does not have to mean the complete replacement of the market mechanism by directives from the government or parliament, but only a completely new state interventionism. The authorities' task is, first and foremost, to stimulate and create economic growth, employment and production, protection against threats, and sustainable development. Particularly in times of pandemics and crisis management. 


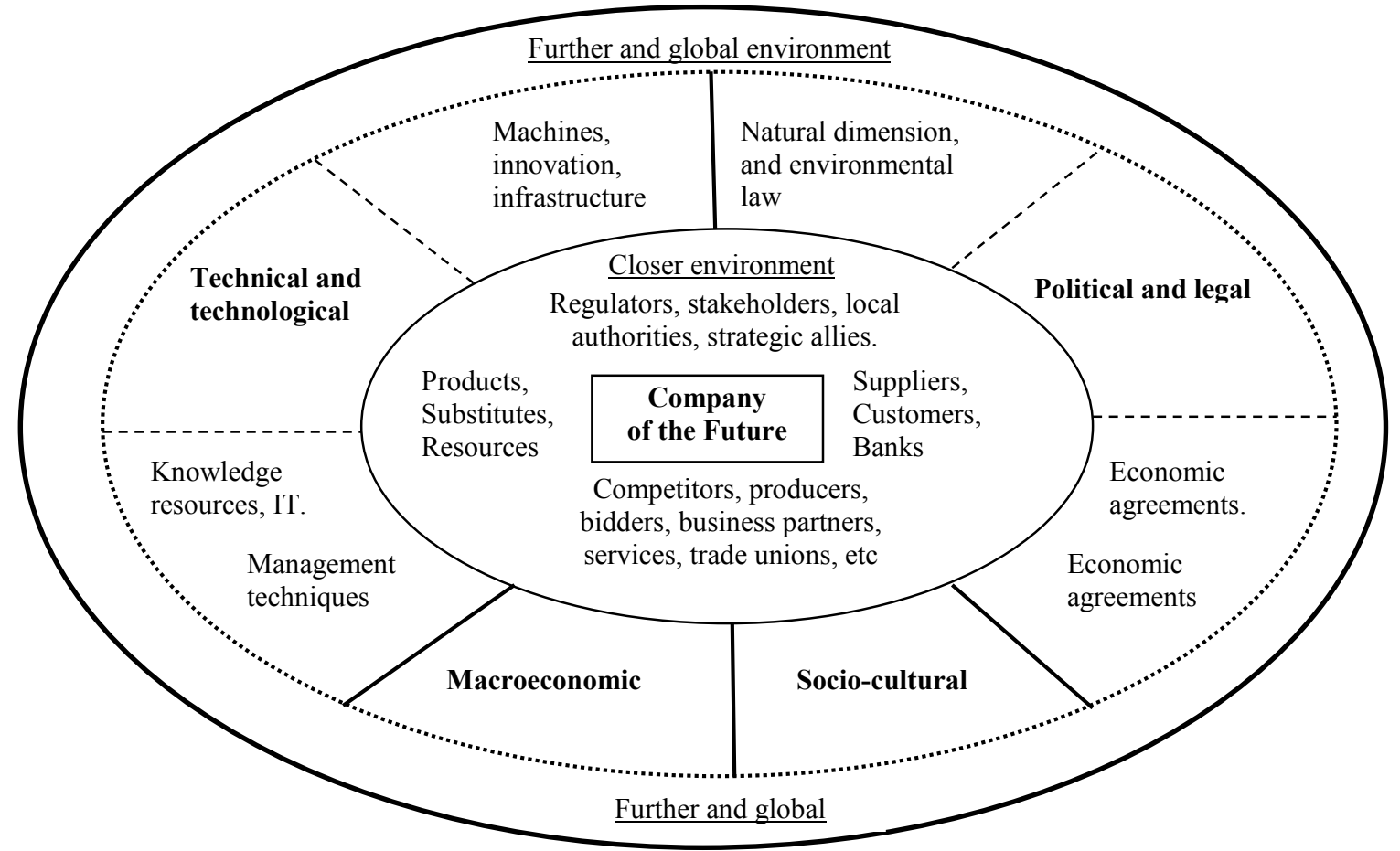

Figure 1. Surroundings of the enterprise of the future. Source: Own study, based on (Griffin, 2010).

Polish enterprises operating under Polish law, even with foreign capital, in future should become a monitored sustainable enterprise, taking into account social and economic factors as well as the elements of the natural environment which make it live (Toczyski, 2004). The literature on the subject also mentions the need for greater social control over the activity of the company and corporation. Moreover, it seems that for the proper course of the globalisation process and for enterprises of the future, continued sustainable development is necessary (Bluszcz, 2017), its education and corporate social responsibility (Pollok, 2015). Too great economic inequalities and concentration of capital in the world are also a problem (Piketty, 2015). Bureaucracy and the distribution of EU money without thinking, and the collection of excessive taxes and fees of any kind, do not really serve the EU as a whole and within the global market. Similarly, environmental protection in the EU, in general, results in a significant increase in production costs, which further reduces the competitiveness of EU enterprises, including Polish enterprises, in comparison to such ones as those from China. However, environmental protection in the EU is important (Muszyńska, Mazur, 2014), as well as the problems of environmental monitoring (Poskrobko, 2012). In Poland, gas and renewable energies should be subsidised more, and coal less, so that there is no smog and health problems associated with this, as well as greater resistance to viruses as part of the epidemic. In fact, Poland's coal mines are becoming deeper and more expensive. Economic development and entrepreneurial optimism are measured mainly by the GDP growth rate in $\%$, but this is not enough, because the whole welfare of people's lives, which is related to health and continued sustainable development, is not taken into account. Preferences concerning various elements of management, economy and life of selected 42 employees of SME enterprises in Małopolska region are presented in Table 3. 
Table 3.

Employees' preferences for the different elements of management, economy and life

\begin{tabular}{|l|l|c|c|c|c|}
\hline \multicolumn{1}{|c|}{ What are the most important elements in management and life yes or no? } \\
\hline Item & Elements: & $\begin{array}{c}\text { Yes } \\
\text { Generally } \\
\text { yes }\end{array}$ & $\begin{array}{c}\text { Generally } \\
\text { no }\end{array}$ & No \\
\hline 1. & Economic and financial (e.g. earnings, prices, investments, costs) & 33 & 7 & 2 & 0 \\
\hline 2. & Family & 33 & 5 & 2 & 2 \\
\hline 3. & Qualifications and experience & 26 & 13 & 3 & 0 \\
\hline 4. & Health and healthy food & 26 & 13 & 3 & 0 \\
\hline 5. & Social (e.g. social, living conditions) & 24 & 16 & 2 & 0 \\
\hline 6. & Leisure & 23 & 15 & 4 & 0 \\
\hline 7. & Ecological (e.g. clean water and air) & 22 & 15 & 3 & 2 \\
\hline 4. & Technology, knowledge, new technologies & 21 & 20 & 1 & 0 \\
\hline 9. & Work & 21 & 18 & 3 & 0 \\
\hline 6. & Legal (e.g. legislation, justice) & 14 & 19 & 9 & 0 \\
\hline 7. & Political (political system, global situation) & 7 & 18 & 17 & 0 \\
\hline
\end{tabular}

Source: Own surveys January-February 2020 in SME sector, Małopolska and Krakow.

Elements of life related to finance, family, health, qualifications, come to the fore here, but also social and ecological aspects, leisure is also very important. Less importance is attached to legal and political aspects at home and abroad. In some cases, respondents point out that technological elements are less important, which may be related to their specific work, rather not innovative, or their beliefs in modern technologies that have flaws and imbalances in the environment.

\section{Conclusion}

The basic condition for the survival of businesses, economies and people is to adapt to the prevailing changing environmental conditions. As a result of the surprise of the pandemic, this environment is changing rapidly. Hence the need to look for modern technologies not only in medicine, but also in terms of management elements, modern management concepts (Bitkowska, Weiss, 2015; McNeil, 2015), crisis management and the use of media in modern enterprise and economy (Nadolna, 2014), as well as better use of IT. The use of broad knowledge and IT to overcome pandemics or similar threats is necessary and gives its positive results for the reduction of adverse phenomena. However, it seems that it is much more difficult to resolve the economic crisis using these technologies, because a crisis or economic slowdown affects all countries of the world. It has accumulated for many years. In addition, this crisis or economic slowdown is strongly affecting precisely those countries which are using IT and modern telecommunications on a massive, widespread scale and want to follow the model of a developed global information society without borders. Important strategic products must be produced in the countries or regions concerned, and everything cannot be transferred to China, for example. 
The IT industry continues to grow, despite the pandemic and the announced adverse economic data. As you can see, there is a high demand for it and for the employees. And the socially learned behaviours of the pandemic will continue to exist even later, building further development for the IT industry. Health, work, family, economic, social and even environmental elements are of great importance to workers, as emerged from questionnaire surveys.

However, the massive use of new technologies has resulted in greater consumption of natural resources, interference with the environment and demand for energy. This causes specific problems and possibly barriers to the further development of a knowledge-based and IT-based society.

Today, companies and organisations need to make rational use of all available innovations (Kraśnicka, 2018), also in the field of IT, telecommunications, management and medicine, of course, in order to overcome the pandemic and economic crisis. It is necessary to apply the so-called modern management methods and techniques, computer-based simulation methods and decision-making in various conditions, using the concepts of research in business and management (Easterby-Smith et al., 2012; Myers, 2013). The organisations of the future will probably follow the needs of humanity in their trends, overcoming epidemics and crises, using innovations, modern technologies including IT and modern management methods. Although there are currently attempts to open economies, because there is a threat of an economic crisis, the situation with a pandemic in the world is still serious. According to data from June 2020 of the Johns Hopkins University, Baltimore, the number of people infected worldwide was over 7.4 million, and a total of 417,000 people died, including 113,000 in the USA (fakty.interia.pl/...). The second wave of the pandemic in the autumn and winter of 2020 will probably bring even more victims, the closure of borders and economies, states of emergency and the deepening of the economic crisis in many countries, especially in America, Europe and Africa. However, the Far East in Asia is already more resistant to pandemics. The next few years may, unfortunately, be similar for people and the economy due to the seasonality of the disease and the generation of successive virus mutations.

\section{Acknowledgements}

Publications and research financed from subsidies to "maintain and develop research potential", thanks to AGH University of Science and Technology, Management Faculty, Krakow, Poland. 


\section{References}

1. Bitkowska, A., Weiss, E. (2015). Wybrane koncepcje zarządzania przedsiębiorstwem. Teoria i praktyka. Warszawa: VIZJA PRESS \& IT.

2. Bluszcz, A. (2017). Metody oceny poziomu zrównoważonego rozwoju. Polska na tle Unii Europejskiej. Zeszyty Naukowe Politechniki Ślaskiej, Organizacja i zarządzanie, z. 118, Nr kol. 1983. Zabrze: Wydawnictwo Politechniki Śląskiej.

3. Borowiecki, R. (2010). Analiza i diagnostyka ekonomiczna w zarządzaniu procesem zmian w przedsiębiorstwie. In: R. Borowiecki, A. Jaki (eds.), Współczesne problemy analizy ekonomicznej. Kraków: Wydawnictwo Uniwersytetu Ekonomicznego.

4. Easterby-Smith, M., Thorpe, R., Jackson, P. (2012). Management research. London: SAGE Publications.

5. Griffin, R.W. (2010). Podstawy zarzadzania organizacjami. Warszawa: PWN.

6. https://cyfrowa.rp.pl/it/47355-firmy-technologiczne-rosna-na-pandemii-kto-zyskujenajwiecej, 30.05.2020

7. https://fakty.interia.pl/raporty/raport-koronawirus-chiny/aktualnosci/news-koronawirusuniwersytet-hopkinsa-ponad-2-mln-zakazen-w-usa,nId,4548705, 10.06.2020.

8. https://mfiles.pl/pl/index.php/Czwarta_rewolucja_przemys\%C5\%82owa, 30.05.2020.

9. https://www.computerworld.pl/news/Informatyka-a-koronawirus-Technologie-w-czasachkryzysu,420082.html, 04.062020.

10. https://www.forbes.pl/gospodarka/koronawirus-prognozy-gospodarcze-mfw/d742kyd, 30.05 .2020

11. https://www.forbes.pl/gospodarka/koronawirus-prognozy-gospodarcze-mfw/d742kyd 30.05.2020.

12. https://www.komputerswiat.pl/aktualnosci/internet/rekordowe-obciazenie-sieci-podczaspandemii-koronawirusa-w-polsce-wzrosty-o-140-proc/8t9sd3s, 30.052020.

13. https://www.obserwatorfinansowy.pl/bez-kategorii/rotator/nie-wszystkie-gospodarkiwpadna-w-recesje/, 30.05.2020.

14. https://www.pulshr.pl/zarzadzanie/kryzys-sie-skonczy-a-branza-it-urosnie-wsile, 72895.html, 05.06.2020.

15. Kalinowski, B. (2015). Wpływ dojrzałości procesowej na efektywność organizacji. Marketing i Rynek, 5. Warszawa: PWE, pp. 1030-1035.

16. Kapferer, J.N. (2012). The new strategic brand management advanced insights and strategic Thinking. Fifth edition. London: Kogan Page.

17. Kasprzak, T. (2003). Biznes i technologie informacyjne. Warszawa: Wyd. Uniwersytetu Warszawskiego.

18. Kraśnicka, T. (2018). Innowacje w zarządzaniu, nowe ujęcie. Warszawa: C.H.Beck. 
19. McNeil, A.J., Frey, R., Embrechts, P. (2015). Quantitative risk management, concepts, techniques and tools. New Jersey: Princeton University Press.

20. Muszyńska, E., Mazur, G. (2014). Unia Europejska 2014. Warszawa: Difin.

21. Myers, M.D. (2013). Quantitative Research in Business \& Management. London: SAGE Publication.

22. Nadolna, M., Skowronek-Mielczarek, A. (2014). Zarzadzanie procesami, a nowoczesne przedsiębiorstwa medialne. Warszawa: CeDeWu.

23. Piketty, T. (2015). Kapitat w XXI wieku. Warszawa: Wydawnictwo Krytyki Politycznej.

24. Pollok, A. (2015). Edukacja dla zrównoważonego i trwałego rozwoju oraz społeczna odpowiedzialność biznesu. Warszawa: Wydawnictwo PTE.

25. Poskrobko, B., Poskrobko, T. (2012). Zarządzanie środowiskiem w Polsce. Warszawa: PWE.

26. Schwab, K. (2018). Czwarta rewolucja przemysłowa. Łódź: Studio Emka.

27. Toczyski, W. (2004). Monitoring rozwoju zrównoważonego i trwałego. Gdańsk: Wydawnictwo Uniwersytetu Gdańskiego. 